Neth. J. PI. Path. 96 (1990) 343-364

\title{
Simulation of damage in winter wheat caused by the grain aphid Sitobion avenae. 1. Quantification of the effects of honeydew on gas exchange of leaves and aphid populations of different size on crop growth
}

\author{
W.A.H. ROSSING and L.A.J.M. VAN DE WIEL
}

Department of Theoretical Production Ecology, Wageningen Agricultural University, P.O. Box 430, 6700 AK Wageningen, the Netherlands

Accepted 30 October 1990

\begin{abstract}
Damage in winter wheat caused by the grain aphid Sitobion avenae F., was studied in the laboratory and at field level.

Honeydew substitute solution was applied to flag leaves of winter wheat plants. One and fifteen days after application, the rates of net carbon dioxide assimilation and transpiration were measured. The rate of dark respiration was significantly higher one day after application of honeydew substitute as compared to the control. Other parameters describing the carbon dioxide - light response were not significantly affected. Fifteen days after honeydew substitute application, the two experimental years yielded different results. Under hot and dry conditions, the rate of dark respiration was higher while the rate of carbon dioxide assimilation at high irradiance, the mesophyll conductance and the leaf nitrogen content were lower than for the untreated control. In addition, chlorotic symptoms were visible. At moderate temperature and relative humidity, the initial light use efficiency was significantly lower fifteen days after treatment with honeydew substitute whereas other parameters were not significantly affected.

In field experiments at two locations natural aphid populations consisting of mainly $S$. avenae were treated weekly with an aphicide from crop development stages DC 71, 73, 75 and 77, respectively, to create infestations of different size and duration. In the unsprayed controls densities reached 15.8 and 44.4 aphids per tiller, amounting to 182 and 544 aphid-days, respectively. Crop samples were analysed weekly, starting at flowering. At the smaller natural infestation, no significant effect on any yield component nor on yield was found at any treatment. The larger infestation caused a significant reduction of leaf area index, leaf weight, amount of water-soluble carbohydrates and grain weight on various sample dates when the infestation was not sprayed before DC 75. No effects were found on tiller and grain density nor on nitrogen content of plant parts at harvest.
\end{abstract}

Additional keywords: photosynthesis, carbon dioxide assimilation.

\section{Introduction}

Aphids infesting cereal crops constitute an irregularly occurring economic problem in western Europe (Watt, 1983). In the Netherlands, Sitobion avenae F. and Metopolophium dirhodum Wlk. are the most abundant species in winter wheat (Triticum aestivum (L.)), Rhopalosiphum padi L. occurring in lower densities (Carter et al., 1982). Although both $S$. avenae and $M$. dirhodum can cause significant damage (Ankersmit and Carter, 
1981; Holt et al., 1984), S. avenae usually attains higher densities under Dutch conditions. Therefore, attention is focussed on $S$. avenae in this paper.

In supervised crop protection, analysis of costs and benefits of chemical control is carried out to establish the pest density at which pesticide use pays off (Zadoks, 1985; Drenth et al., 1989; Zadoks, 1989). Such analysis requires information on the population dynamics and the damage caused by the pest. The population dynamics of S. avenae has been studied extensively, considering both temporal (e.g. Carter et al., 1982) and spatial aspects (e.g. Rabbinge and Mantel, 1981). This paper considers the effect of injury by the grain aphid $S$, avenae on the yield of winter wheat.

Studies on the effect of injury by $S$. avenae and $M$. dirhodum on wheat yield indicate that damage is a complex function of the distribution of aphids over the plant, the duration and the size of the aphid infestation, and factors which determine and limit crop growth (Wratten, 1975, 1978; Wratten and Redhead, 1976; Entwistle and Dixon, 1987; Wellings et al., 1989). In an early report (Van Roermund et al., 1986a, b), we applied a systems approach making use of a simulation model. Essential processes of the $S$. avenae - winter wheat system were described and quantified in a simulation model, which was then used to predict the dynamics of the state of the system. The system consisted of a sufficiently large field of winter wheat growing at the prevailing weather conditions, the available amount of soil nitrogen and the aphid infestation present. Water limitation was not included. The processes distinguished were photosynthesis, uptake of nitrogen from the soil and distribution of carbohydrates and nitrogen over various plant parts. In the model, $S$. avenae affected both the availability of carbohydrates and nitrogen for the grains (Rabbinge and Coster, 1984) and the rate of carbon dioxide assimilation (Rabbinge et al., 1981). Variables describing the state of the system were crop development stage and dry weight and nitrogen content of plant organs. Preliminary runs with the simulation model showed the effect of honeydew on photosynthesis to be a significant component of damage. The information available concerns mainly the effects of honeydew immediately after application to leaves (Rabbinge et al., 1981). Data on the effects after a longer period of time are limited and also, data to evaluate the performance of the model are needed.

This paper reports results of experiments in which the short and medium term effects of honeydew on gas exchange of flag leaves of winter wheat were quantified. Secondly, the results of field experiments to establish the effect of $S$. avenae populations of various size and duration on crop growth and production are presented.

\section{Material and methods}

References to crop development stage are in Decimal Code (DC) (Zadoks et al., 1974). Weights are expressed in terms of dry matter.

\section{The effect of honeydew on gas exchange of leaves}

In a series of gas exchange experiments, the effect of honeydew of $S$. avenae on parameters characterizing the carbon dioxide assimilation - light curve was established. To ensure a sufficiently large supply of honeydew, a substitute solution was prepared, reflecting the amino-acid and ugar composition of real honeydew. This composition was determined in a separate experiment carried out before the start of the gas exchange studies. 
Chemical composition of honeydew. To determine the chemical composition of honeydew excreted by $S$. avenae feeding on winter wheat, 20 healthy winter wheat plants (cv. Arminda, DC 61), grown on a clay soil (30-65\% lutum) near Wageningen, the Nether-

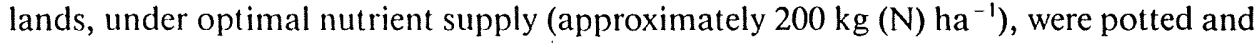
transferred to a greenhouse (average temperature $18{ }^{\circ} \mathrm{C}, 90 \%$ relative humidity). Apterous adult $S$. avenae, collected from a virus-free culture, were confined to the ears using perspex leaf cages (Vereijken, 1979): Each cage contained approximately 40 aphids. After three days, the cages were removed and rinsed with a small amount of warm demineralized water. The solution was filtered to remove exuvia and dirt and stored at $-18{ }^{\circ} \mathrm{C}$. Amino-acids were analysed by high pressure liquid chromatography. Sugars were determined volumetrically according to the method of Schaffer and Somogyi (1933), adapted by Vertregt and Verhagen (1979). The method distinguishes between monosaccharides (glucose and fructose) and higher sugars: di- and oligo-saccharides. Using an ultrasonic bath, a 25 (weight-) $\%$ honeydew substitute solution was prepared for use in the experiments, similar in amino-acid composition to real honeydew, using glucose and sucrose as sugars.

Plant material for the gas exchange experiments. In March 1986, winter wheat plants, cv. Arminda (DC 12), grown outdoors were transferred to $26 \mathrm{~cm}$ diameter buckets (content 5 liter) filled with clay soil (22\% lutum) and supplied with an abundant fertilizer rate of phosphate and potassium. Five plants were potted in each bucket. The buckets were dug into the ground, arranged in a rectangle, mimicking the natural crop structure. To prevent border effects, a strip of one meter around the plot was sown to spring wheat. At development stages DC 14-15 and DC 23, nitrogen fertilizer was applied at a rate of 1 and 2 gram ammonium-nitrate per bucket, respectively. Water was supplied when necessary. One day prior to treatment the buckets were dug up and transferred to a roofed part of the experimental site to prevent rain from washing off the honeydew during the experiment. The plants were sprayed with triadimenol (Baytan, $0.5 \mathrm{~g}^{-1}$ ) during the second week of the experiment to control a beginning powdery mildew infection.

In 1987, winter wheat plants (cv. Urban) were not transferred to pots because of extremely wet field conditions in March. The plants remained at an experimental farm at Nagele, North East Polder and were subjected to normal farm practice until the start of the experiment in July. Total soil nitrogen amounted to $275 \mathrm{~kg} \mathrm{ha}^{-1}$. Weeds, mildew and aphids were controlled chemically.

Experimental procedure and data analysis. Both in 1986 and 1987, flag leaves of winter wheat plants were given one of the following treatments: no applications (control), application of water (water), single application of honeydew substitute (hdl) and twice an application of honeydew substitute, waiting half an hour between applications (hd2). The latter two treatments were aimed at creating honeydew substitute deposits of different size. Honeydew substitute was applied with a pipette and gently spread over the adaxial leaf surface of the flag leaves with the forefinger.

For the measurements, plants were moved to the laboratory. In 1987, plants were dug up carefully and individually transferred to 51 buckets. The soil-moisture level was maintained at field capacity.

Rates of carbon dioxide assimilation, respiration and transpiration of flag leaves were 
measured, using laboratory equipment for routine measurements of photosynthesis comparable to the type described by Louwerse and Van Oorschot (1969). Relative humidity in the leaf chambers was approximately $50-60 \%$ and air temperature was $23{ }^{\circ} \mathrm{C}$. Four or five flag leaves of main stems from at least two different buckets were included in each leaf chamber. Net carbon dioxide assimilation, transpiration, stomatal resistance and carbon dioxide concentration inside the substomatal cavity were calculated according to the procedure of Goudriaan and Van Laar (1978).

The measurements were carried out one and fifteen days after treatment. In addition, carbon dioxide assimilation of flag leaves treated twice with honeydew substitute was measured three days after treatment in 1987 (abbreviated as hd3d) to evaluate whether effects found one day after treatment persisted. In this way, short and medium-term effects of honeydew were quantified. Evaluation of long-term effects (after 4 to 5 weeks) are beyond the scope of this paper.

Two series of measurements were carried out. In the first, irradiance was varied from $0 \mathrm{~J} \mathrm{~m}^{-2} \mathrm{~s}^{-1}$ to approximately $300 \mathrm{~J} \mathrm{~m}^{-2} \mathrm{~s}^{-1}$ in 6 steps at a constant ambient carbon dioxide concentration of $632 \mathrm{mg} \mathrm{m}^{-3}(345 \mathrm{ppm})$. The carbon dioxide assimilation light response curve is described by a negative exponential function (Goudriaan, 1982):

$$
P_{\mathrm{n}}=\left(P_{\mathrm{m}}+R_{\mathrm{d}}\right)\left(1-\exp \left(-\epsilon I /\left(P_{\mathrm{m}}+R_{\mathrm{d}}\right)\right)\right)-R_{\mathrm{d}}
$$

where $P_{\mathrm{n}}=$ net carbon dioxide assimilation rate $\left(\mu \mathrm{g}\left(\mathrm{CO}_{2}\right) \mathrm{m}^{-2} \mathrm{~s}^{-1}\right), P_{\mathrm{m}}=$ carbon dioxide assimilation rate at light saturation and an ambient carbon dioxide concentration of $632 \mathrm{mg} \mathrm{m}^{-3}\left(\mu \mathrm{g}\left(\mathrm{CO}_{2}\right) \mathrm{m}^{-2} \mathrm{~s}^{-1}\right), R_{\mathrm{d}}=$ dark respiration rate $\left(\mu \mathrm{g}\left(\mathrm{CO}_{2}\right) \mathrm{m}^{-2} \mathrm{~s}^{-1}\right)$, $\epsilon=$ initial light use efficiency $\left(\mu \mathrm{g}\left(\mathrm{CO}_{2}\right) \mathrm{J}^{-1}\right), I=$ absorbed photosynthetically active radiation (PAR, $\mathrm{J} \mathrm{m}^{-2} \mathrm{~s}^{-1}$ ).

The parameters $P_{\mathrm{m}}, R_{\mathrm{d}}$ and $\epsilon$ were determined for each leaf chamber, using a nonlinear least squares regression procedure (SAS, 1985).

In the second series the ambient carbon dioxide concentration was increased to 900 $\mathrm{ppm}$ and decreased to $50 \mathrm{ppm}$ in discrete steps, at maximum irradiance of $c a 300 \mathrm{~J}$ $\mathrm{m}^{2} \mathrm{~s}$ '. Carbon dioxide assimilation was related to internal $\mathrm{CO}_{2}$ concentration to eliminate the variation in stomatal resistance, using a negative exponential function (Kropff, 1987):

$$
P_{\mathrm{n}}=P_{\mathrm{m}, \mathrm{m}}\left(1-\exp \left(-g_{\mathrm{m}}\left(C_{\mathrm{i}}-\Gamma\right) / P_{\mathrm{m}, \mathrm{m}}\right)\right)
$$

where $P_{\mathrm{m}, \mathrm{ml}}=$ carbon dioxide assimilation rate at carbon dioxide saturation $\left(\mu \mathrm{g}\left(\mathrm{CO}_{2}\right)\right.$ $\left.\mathrm{m}^{-2} \mathrm{~s}^{-1}\right), C_{\mathrm{i}}=$ internal carbon dioxide concentration $\left(\mu \mathrm{g}\left(\mathrm{CO}_{2}\right) \mathrm{m}^{-3}\right), \Gamma=$ carbon dioxide compensation point $\left(\mu \mathrm{g}\left(\mathrm{CO}_{2}\right) \mathrm{m}^{-3}\right), g_{\mathrm{m}}=$ mesophyll conductance $\left(\mathrm{m} \mathrm{s}^{-1}\right)$.

The parameters $P_{\mathrm{m}, \mathrm{m}}, \Gamma$ and $g_{\mathrm{m}}$ were determined per leaf chamber, using a non-linear least squares regrcssion procedure (SAS, 1985).

Differences in parameter values between treatments were evaluated in an analysis of variance. If differences at the $10 \%$ significance level were found, the Student-NewmanKeuls test was carried out to compare treatment means (Snedecor and Cochran, 1980).

After carbon dioxide assimilation measurements in 1986, $\mathrm{MgO}$-powder was dusted onto the leaf area, to mark the area covered with honeydew substitute. The result was photographed for estimation of the leaf area covered. As the outlines of the areas were blurred, this method yielded only a rough estimate. Therefore, instead of measuring 
the area covered, the amount of honeydew applied was determined in a separate experiment, treating 10 flag leaves of winter wheat plants (DC 61) with honeydew substitute as described above. After one day, each leaf was washed with warm, demineralized water and the resulting solutions were pooled. The solution was filtered and freeze-dried and the dried material weighed. The same procedure was followed for 10 leaves treated with water. In 1987, the same procedure was applied to the leaves, immediately after the carbon dioxide assimilation measurements. Also, the amount of nitrogen in the flag leaves used for photosynthesis measurements was determined.

In 1987, the diffuse reflection of photosynthetically active radiation was measured using a spectro-radiometer ( $\mathrm{LiCor} \mathrm{Li}-1800$ ) to establish the additional reflection caused by honeydew.

\section{Quantification of damage in field experiments}

Experimental layout. In 1984, two experiments were carried out at the experimental farms 'de Bouwing' and 'de Eest', the Netherlands. Information on the experimental sites and on crop husbandry practices is given in Table 1 . The experiments were set up according to a randomized block design, with 4 treatments and 6 replications. Plots were $8 \mathrm{~m}$ wide and $11 \mathrm{~m}$ long on 'de Bouwing' and $8 \mathrm{~m}$ wide and $9 \mathrm{~m}$ long on 'de Eest', respectively, yielding a net-plot of $4 \mathrm{~m}$ width and two adjacent buffer strips of $2 \mathrm{~m}$ width each. The latter received the same treatment as the net-plot.

Treatments. Chemical control of cereal aphids (Pirimor, $0.25 \mathrm{~kg} \mathrm{ha}^{-1}$ ) was carried out to create infestations of different size. The treatments consisted of:

A. weekly chemical control of aphids starting at DC 71;

B. weekly chemical control of aphids starting at DC 73;

C. weekly chemical control of aphids starting at DC 75;

D. weekly chemical control of aphids starting at DC 77;

E. no chemical control of aphids.

The treatments started at DC 71, approximately coinciding with aphid immigration. On 'de Bouwing' the aphid population collapsed after DC 75. Therefore treatments $\mathrm{C}$ and $\mathrm{D}$ were omitted. On 'de Eest' treatment $\mathrm{B}$ was not carried out due to technical problems.

Crop analysis and aphid sampling. Samples of 50 ear-bearing tillers chosen at random from the buffer of each plot, were harvested at weekly intervals, from flowering (DC 60) until final harvest (DC 92). After assessment of the development stage, the tillers were divided into ear, leaf lamina and stem fractions. The stem fractions included ligules, auricules and leaf sheaths in addition to the true stem. Leaf laminae were further divided into living and dead tissue fractions. Living leaf area was measured using a leaf area meter (Licor Li-3100). Dry weights of the fractions were determined after drying at $105^{\circ} \mathrm{C}$ for $15 \mathrm{~h}$. The stem fractions were dried at $70^{\circ} \mathrm{C}$ for $15 \mathrm{~h}$ to enable subsequent chemical analysis of water-soluble carbohydrates. After threshing and drying at $105{ }^{\circ} \mathrm{C}$ for $15 \mathrm{~h}$, grain dry weight and 1000 kernel weight were determined. The nitrogen content of the fractions and the amount of soluble carbohydrates in the stem fraction were determined at 2 to 3 weekly intervals starting at flowering (day 179 at 'de Eest' and day 172 at 'de Bouwing'). Final grain yield was also determined by combine harvesting.

Neth. J. Pl. Path. 96 (1990) 
Table 1. General information on the field experiments at the experimental farms 'de Bouwing' and 'de Eest'.

\begin{tabular}{|c|c|c|}
\hline & de Bouwing & de Eest \\
\hline Location & Randwijk, central river-clay area & Nagele, sea-clay area \\
\hline Cultivar & Arminda & Arminda \\
\hline Soil type & clay $35-55 \%$ & clay $33 \%$ \\
\hline Previous crop & potatoes & sugar beets \\
\hline Sowing date & 22 October 1983 & 4 November 1983 \\
\hline Sowing rate & $138 \mathrm{~kg} \mathrm{ha}^{-1}$ & $148 \mathrm{~kg} \mathrm{ha}^{-1}$ \\
\hline $\mathrm{N}$-mineral $\left(\mathrm{kg} \mathrm{ha}^{-1}\right)^{*}$ & 60 & 80 \\
\hline $\mathrm{N}$ fertilization ( $\left.\mathrm{kg} \mathrm{ha}^{-1}\right)$ & $80+65$ & $60+80+50$ \\
\hline Weed control & 22 Oct $: 81 \mathrm{ha}^{-1}$ Tok Ultra & 4 May: 81 ha $^{-1}$ DM68 \\
\hline Disease control & $\begin{aligned} 15 \mathrm{May}: & 0.5 \mathrm{~kg} \mathrm{ha}^{-1} \text { Bayleton }+ \\
& 2 \mathrm{~kg} \mathrm{ha}-1 \text { maneb } \\
15 \mathrm{June}: & 3 \mathrm{~kg} \mathrm{ha}^{-1} \text { Corbeltop } \\
18 \mathrm{July}: & 2 \mathrm{~kg} \mathrm{ha}^{-1} \text { Bayleton } \mathrm{CF}+ \\
& 2 \mathrm{~kg} \mathrm{ha}^{-1} \text { maneb }\end{aligned}$ & 20 June: $\begin{aligned} & 0.5 \mathrm{~kg} \mathrm{ha}^{-1} \text { Bayleton }+ \\
& 2 \mathrm{~kg} \mathrm{ha}^{-1} \text { maneb }+ \\
& 1 \mathrm{~kg} \mathrm{ha}^{-1} \text { Captafol }\end{aligned}$ \\
\hline Plant density at flowering & $546 \pm 59(\mathrm{SEM})$ & $636 \pm 56(\mathrm{SEM})$ \\
\hline Yield of treated control & $8754 \pm 461(\mathrm{SEM})$ & $8114 \pm 559(\mathrm{SEM})$ \\
\hline
\end{tabular}

* Amount of soil nitrogen available in February.

The crop at 'de Eest' was treated with glyphosate one week prior to harvest as the straw was still partly green, although the ears were ripe.

The size of the aphid population was monitored by recording the aphid incidence (i.e. presence on a tiller) in a sample of 100 tillers per plot. If incidence was lower than $10 \%$ or higher than $90 \%$ the absolute number of aphids on 100 tillers per plot was recorded. In this way, the coefficient of variation in the population estimates was less than $c a$ 10\% (Ward et al., 1985). Monitoring started at DC 40. The aphid-index (Rautapää, 1966) was calculated by integrating the aphid density over time, using linear interpolation to calculate aphid density between data points.

Differences between treatments were evaluated in an analysis of variance. If differences at the $5 \%$ significance level were found, treatments were ranked according to the Student-Newman-Keuls test.

\section{Results}

The effect of honeydew on gas exchange of leaves

Chemical composition of honeydew. The amino-acid and sugar composition of honeydew of $S$. avenae is shown in Table 2. Of the 13 amino-acids identified, threonine was present in the largest amount. Mono- and higher saccharides occurred in approximately equal amounts.

Weather conditions during the gas exchange experiments. The time courses of daily maximum and minimum temperatures in 1986 and 1987 and the amount of precipitation in 1987 are shown in Fig. 1. Daily temperature was higher in 1986 with maximum values frequently exceeding $25^{\circ} \mathrm{C}$. During the second half of the experimental period 
Table 2. Chemical composition of honeydew of Sitobion avenae, feeding on ears of winter wheat, development stage DC 61. The weight-ratio of sugar and amino-acids is 46 .

\begin{tabular}{lllr}
\hline Sugars & $\%$ & Amino-acids & $\%$ \\
glucose, fructose & 51.5 & alanine & 3.7 \\
higher saccharides & 48.5 & aspartic acid & 7.9 \\
& & glutamic acid & 6.3 \\
& glycine & 2.3 \\
& histidine & 9.8 \\
& isoleucine & 4.5 \\
& leucine & 7.3 \\
& lysine & 2.5 \\
& proline & 8.0 \\
& & phenylalanine & 6.3 \\
& & threonine & 26.3 \\
& & tyrosine & 7.3 \\
& & valine & 7.8 \\
\hline & & & 100
\end{tabular}
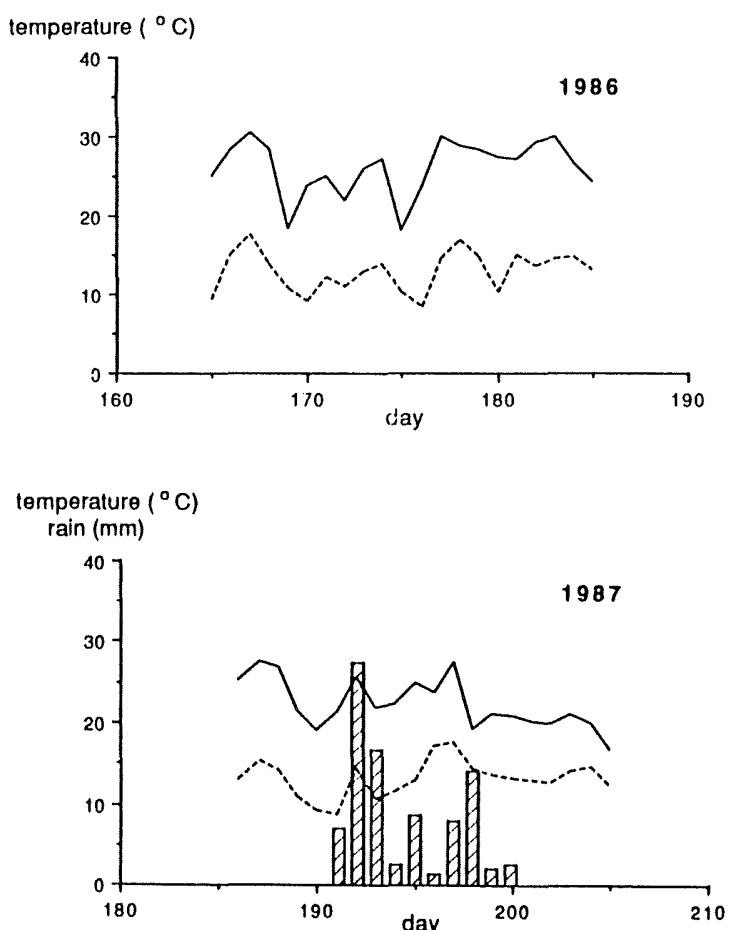

Fig. 1. Daily maximum ( _ $)$ and minimum ( -.-.-.-- ) temperatures $\left({ }^{\circ} \mathrm{C}\right)$ during the experiments in 1986 and 1987 and precipitation $(\mathrm{mm}, \square)$ in 1987. Precipitation was absent in 1986.

Neth. J. Pl. Path. 96 (1990) 
in 1987, heavy thunderstorms occurred. In 1987, dew was recorded on the leaves, whereas in 1986 plants remained dry throughout the experimental period as a result of their sheltered position.

Honeydew amount and leaf coverage. In 1986, $6.4 \mathrm{~g} \mathrm{~m}^{-2}$ honeydew substitute was recovered one day after single application compared to $10.9 \mathrm{~g} \mathrm{~m}^{-2}$ after double application. The fraction of the leaf area covered amounted to 50-60\% in both treatments. No measurements of the amount of honeydew substitute were carried out fifteen days after application.

In 1987, differences between the treatments were small. One day after treatment, the total amount recovered was $2.8 \pm 0.7(\mathrm{SEM}) \mathrm{g} \mathrm{m}^{-2}$ and $2.3 \pm 0.6(\mathrm{SEM}) \mathrm{g} \mathrm{m}^{-2}$ for single and double application, respectively. The fraction of leaf area covered varied from $10 \%$ to $20 \%$ in both treatments. After fifteen days, no differences with the water treated control were measured. Because of the similarity in the amount of honeydew recovered, the results of the treatments hdl and hd 2 were lumped before analysis, indicated as hd. Three days after double application, the total amount of honeydew recovered was $2.2 \pm 1.2(\mathrm{SEM}) \mathrm{g} \mathrm{m}^{-2}$. Here too, the fraction of leaf area covered amounted to 10 to $20 \%$.

Effects of honeydew on carbon dioxide assimilation - light response. The results
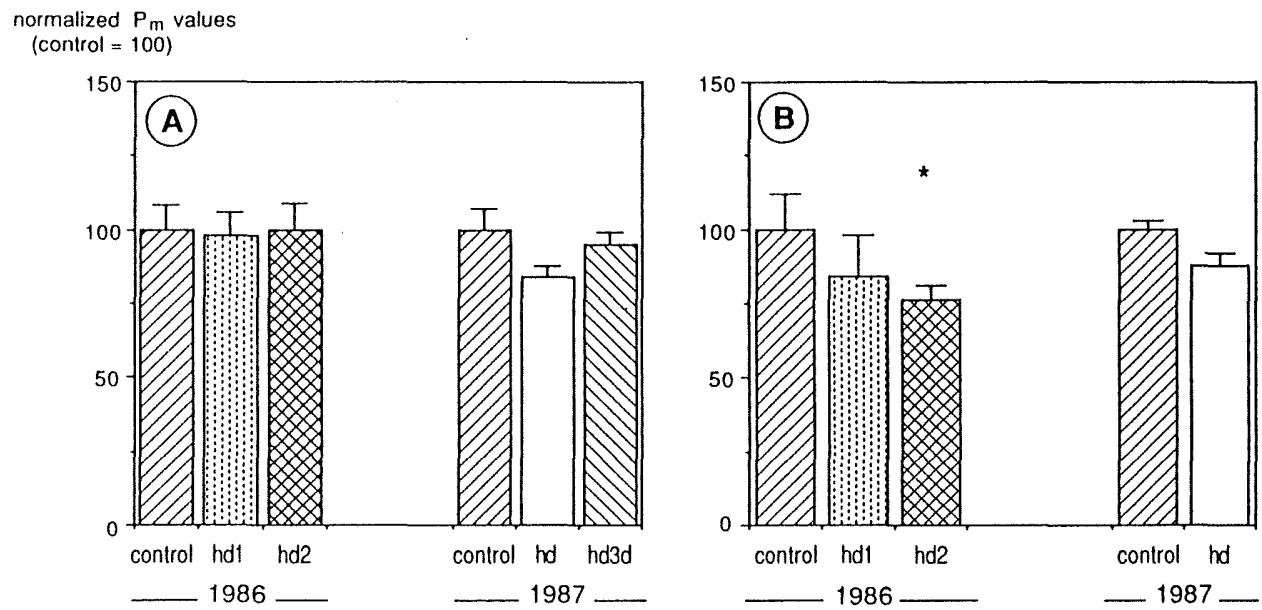

Fig. 2. Normalized estimated parameter values of the rate of carbon dioxide assimilation at high irradiance $\left(P_{\mathrm{m}}\right)$ of flag leaves of winter wheat treated with honeydew substitute. A: one day (hd1, hd2, hd) and three days after treatment (hd3d); B: fifteen days after treatment.

A description of the treatments is given in the text. Error bars represent the normalized standard error of the mean. An asterisk above a bar indicates a significant difference as compared to the water treated control $(p<0.10)$.

For the control treatment in 1986, the values of $P_{\mathrm{m}}$ were $($ mean $\pm \mathrm{SEM}): P_{\mathrm{m}}=1.50 \pm 0.11$ $\mathrm{mg} \mathrm{CO} 2 \mathrm{~m}^{-2} \mathrm{~s}^{-1}$ after one day and $P_{\mathrm{m}}=1.23 \pm 0.14 \mathrm{mg} \mathrm{CO}_{2} \mathrm{~m}^{-2} \mathrm{~s}^{-1}$ after fifteen days.

For the control treatment in 1987, values of $P_{\mathrm{m}}$ were (mean $\pm \mathrm{SEM}$ ): $P_{\mathrm{m}}=0.77 \pm 0.06 \mathrm{mg}$ $\mathrm{CO}_{2} \mathrm{~m}^{2} \mathrm{~s}^{-1}$ after one day and $P_{\mathrm{m}}=0.77 \pm 0.03 \mathrm{mg} \mathrm{CO}_{2} \mathrm{~m}^{-2} \mathrm{~s}^{-1}$ after fifteen days.

The number of replications is indicated in Table 5 . 
of carbon dioxide assimilation measurements at various light intensities in 1986 and 1987 are shown in Figs. 2, 3 and 4. For brevity, the results of the water treated control are not shown. These did not differ significantly from the untreated control.

Application of honeydew substitute resulted in a significant reduction of the rate of carbon dioxide assimilation at high irradiances fifteen days after double application under the hot and dry conditions of 1986 (Fig. 2). Otherwise changes in $P_{\mathrm{m}}$ were minor after treatment.

The rate of dark respiration was increased significantly one day after treatment in both experimental years. Three days after application in 1987 however, values of $R_{\mathrm{d}}$ were comparable to the control. Fifteen days after treatment, a significant increase in $R_{\mathrm{d}}$ was measured in 1986 following double honeydew application (Fig. 3).

The initial light use efficiency was significantly reduced in 1987 fifteen days after application (Fig. 4). Other treatments with honeydew substitute did not have a clear effect.

The ratio of carbon dioxide assimilation and transpiration $(P / T)$ and the ratio of internal and ambient carbon dioxide concentrations $\left(C_{\mathrm{i}} / C_{\mathrm{a}}\right)$ were not affected by the honeydew treatments, except after double application in 1986 (Table 3). In the latter case, the ratio of assimilation and transpiration was reduced after both one and fifteen days, while the ratio of internal and ambient carbon dioxide concentration was increased one day after application.
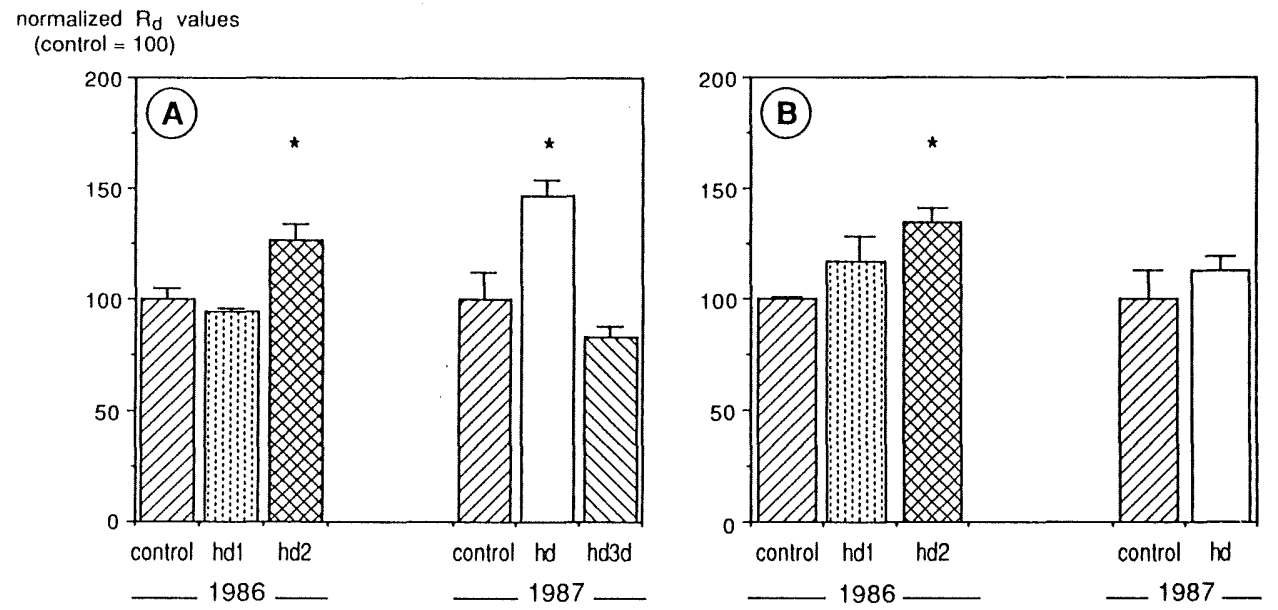

Fig. 3. Normalized estimated parameter values of the rate of dark respiration $\left(R_{\mathrm{d}}\right)$ of flag leaves of winter wheat treated with honeydew substitute. A: one day (hdl, hd2, hd) and three days after treatment (hd3d); B: fifteen days after treatment.

A description of the treatments is given in the text. Error bars represent the normalized standard error of the mean. An asterisk above a bar indicates a significant difference as compared to the untreated control $(p<0.10)$.

For the control treatment in 1986, the values of $R_{\mathrm{d}}$ were (mean $\pm \mathrm{SEM}$ ): $R_{\mathrm{d}}=34 \pm 2 \mu \mathrm{g} \mathrm{CO}$ $\mathrm{m}^{-2} \mathrm{~s}^{-1}$ after one day and $R_{\mathrm{d}}=31 \pm 0.3 \mu \mathrm{g} \mathrm{CO}_{2} \mathrm{~m}^{-2} \mathrm{~s}^{-1}$ after fifteen days.

For the control treatment in 1987, values of $R_{\mathrm{d}}$ were (mean $\pm \mathrm{SEM}$ ): $R_{\mathrm{d}}=33 \pm 4 \mu \mathrm{g} \mathrm{CO}_{2} \mathrm{~m}^{-2}$ $\mathrm{s}^{-1}$ after one day and $R_{\mathrm{d}}=20 \pm 3 \mu \mathrm{g} \mathrm{CO} \mathrm{Cm}^{-2} \mathrm{~s}^{-1}$ after fifteen days.

The number of replications is indicated in Table 5 .

Neth. J. Pl. Path. 96 (1990) 



Fig. 4. Normalized estimated parameter values of the initial light use efficiency $\epsilon$ of flag leaves of winter wheat treated with honeydew substitute. A: one day (hd1, hd2, hd) and three days after treatment (hd3d); B: fifteen days after treatment.

A description of the treatments is given in the text. Error bars represent the normalized standard error of the mean. An asterisk above a bar indicates a significant difference as compared to the untreated control $(p<0.10)$.

For the control treatment in 1986, the values of $\epsilon$ were (mean \pm SEM): $\epsilon=12 \pm 1.1 \mu \mathrm{g} \mathrm{CO}_{2}$ $\mathrm{J}^{-1}$ after one day and $13 \pm 1.1 \mu \mathrm{g} \mathrm{CO}_{2} \mathrm{~J}^{-1}$ after fifteen days.

For the control treatment in 1987, values of $\epsilon$ were (mean \pm SEM): $\epsilon=12 \pm 0.6 \mu \mathrm{g} \mathrm{CO}_{2} \mathrm{~J}^{-1}$ after one day and $13 \pm 0.3 \mu \mathrm{g} \mathrm{CO}_{2} \mathrm{~J}^{-1}$ after fifteen days.

The number of replications is indicated in Table 5.

Leaf nitrogen contents are shown in Table 4. In 1986, differences were small one day after treatment. After 15 days, a significant reduction of the nitrogen content was found in leaves treated with honeydew substitute as compared to the untreated control. In 1987, no differences in leaf nitrogen content were found after treatment.

Effects of honeydew on carbon dioxide assimilation - carbon dioxide response. A significant (31\%) decrease in mesophyll conductance occurred fifteen days after double application of honeydew in 1986. Otherwise, parameter values did not differ significantly from the untreated control.

Reflection of photosynthetically active radiation. Average reflection of photosynthetically active radiation was not affected by treatment of leaves with honeydew substitute in 1987.

\section{Quantification of damage in field experiments}

Aphid population dynamics. In both experiments, the aphid population consisted mainly of $S$. avenae, the fraction $M$. dirhodum never exceeding 5\%. R. padi was not found in the samples. Aphid density is shown in Fig. 5. In the untreated (E-)plots peak densities were reached at DC 75, amounting to 15.8 and 44.4 aphids per tiller on 'de 
Table 3. Ratio of rates of photosynthesis and transpiration $\left(P / T, \mathrm{~g} \mathrm{~kg}^{-1}\right)$ and internal and ambient $\mathrm{CO}_{2}$ concentration $\left(C_{\mathrm{i}} / C_{\mathrm{a}}\right)$ of flag leaves of winter wheat one, three and fifteen days after treatment with honeydew substitute. Light intensity was approximately $300 \mathrm{~J} \mathrm{~m}^{-2} \mathrm{~s}^{-1}$. A description of the treatments is given in the text. Different letters following treatments indicate significant differences (ANOVA followed by Student-Newman-Keuls test, $p<0.10$ ).

One and three days after treatment

\begin{tabular}{|c|c|c|c|c|c|c|c|}
\hline \multicolumn{4}{|l|}{1986} & \multicolumn{4}{|l|}{1987} \\
\hline treatment & $n$ & $P / T$ & $C_{\mathrm{i}} / C_{\mathrm{a}}$ & treatment & $n$ & $P / T$ & $C_{i} / C_{\mathrm{a}}$ \\
\hline control & 4 & $1.40 \mathrm{a}$ & $0.60 p$ & control & 4 & $1.11 \mathrm{a}$ & $0.68 \mathrm{p}$ \\
\hline water & 2 & $1.39 \mathrm{a}$ & $0.57 \mathrm{p}$ & water & 2 & $1,16 \mathrm{a}$ & $0.65 p$ \\
\hline hd1 & 2 & $1.36 \mathrm{a}$ & $0.56 \mathrm{p}$ & hd & 8 & $1.13 \mathrm{a}$ & $0.65 \mathrm{p}$ \\
\hline \multirow[t]{2}{*}{ hd2 } & 4 & $1.17 \mathrm{~b}$ & $0.70 \mathrm{q}$ & & & & \\
\hline & & & & $h d 3 d$ & 2 & $1.09 \mathrm{a}$ & $0.70 \mathrm{p}$ \\
\hline
\end{tabular}

Fifteen days after treatment

\begin{tabular}{|c|c|c|c|c|c|c|c|}
\hline \multicolumn{4}{|l|}{1986} & \multicolumn{4}{|l|}{1987} \\
\hline treatment & $n$ & $P / T$ & $C_{\mathrm{i}} / C_{\mathrm{a}}$ & treatment & $n$ & $P / T$ & $C_{\mathrm{i}} / C_{\mathrm{a}}$ \\
\hline control & 2 & $1.37 \mathrm{a}$ & $0.59 \mathrm{p}$ & control & 4 & $0.93 \mathrm{a}$ & $0.75 \mathrm{p}$ \\
\hline water & 2 & $1.35 \mathrm{a}$ & $0.57 \mathrm{p}$ & water & 2 & $1.09 \mathrm{a}$ & $0.73 \mathrm{p}$ \\
\hline hd 1 & 2 & $1.38 \mathrm{a}$ & $0.56 \mathrm{p}$ & hd & 8 & $0.92 \mathrm{a}$ & $0.73 \mathrm{p}$ \\
\hline hd 2 & 4 & $1.18 \mathrm{~b}$ & $0.62 p$ & & & & \\
\hline
\end{tabular}

Bouwing' and 'de Eest', respectively. Chemical control resulted in aphid loads of 17.1 (A), 66.0 (B) and 182.2 (E) aphid-days at 'de Bouwing' and 50.6 (A), 328.6 (C), 481.8 (D) and 544.3 (E) aphid-days at 'de Eest'.

Crop growth analysis. In neither experiment, the tiller density was affected by the aphid populations. This is expected as tiller density is determined before and during booting when no aphids were found. In the calculations constant tiller densities were used, $546 \mathrm{~m}^{-2}$ for 'de Bouwing' and $636 \mathrm{~m}^{-2}$ for 'de Eest', respectively. At 'de Bouwing', treatment E significantly decreased leaf weight and leaf area index as compared to treatment A on two sample dates but no significant effects on grain yield were found (Table 5 and Fig. 6a). Neither stem weight, amount of soluble carbohydrates nor nitrogen fractions of the organs were consistently reduced after aphid infestation. Green leaf area duration was reduced, although not significantly.

At 'de Eest', treatments C, D and E significantly reduced grain yield, grain weight, leaf weight and leaf area index on a number of sampling dates (Fig. 6b and Table 6). Grain density (the number of grains per square meter) was not affected by the treatments. Green leaf area duration was reduced significantly by treatments C, D and E as compared to treatment $\mathrm{A}$ (Table 6). Nitrogen fractions of leaves and ears were reduced significantly in treatment $\mathrm{E}$ (29.7 and $21.2 \mathrm{~g} \mathrm{~kg}^{-1}$, respectively) as compared to treatNeth. J. Pl. Path. 96 (1990) 
Table 4. Nitrogen content ( $(\mathrm{N}) \mathrm{kg}^{-1}$ (dry matter)) of flag leaves of winter wheat one, three and fifteen days after treatment with honeydew substitute. A description of the treatments is given in the text. Different letters following treatments indicate significant differences (ANOVA followed by Student-Newman-Keuls test, $p<0.10$ ).

\begin{tabular}{|c|c|c|c|c|c|}
\hline \multicolumn{5}{|c|}{ One and three days after treatment } & . \\
\hline \multicolumn{3}{|l|}{1986} & \multicolumn{3}{|l|}{1987} \\
\hline treatment & $n$ & $\mathrm{~N}$-content & treatment & $n$ & $\mathrm{~N}$-content \\
\hline control & 4 & $44 \mathrm{a}$ & control & 4 & $35 \mathrm{a}$ \\
\hline water & 2 & $46 a$ & water & 2 & $38 \mathrm{a}$ \\
\hline hd 1 & 2 & $46 a$ & hd & 8 & $36 \mathrm{a}$ \\
\hline \multirow[t]{2}{*}{$h d 2$} & 4 & $43 \mathrm{a}$ & & & \\
\hline & & & hd $3 d$ & 2 & $35 \mathrm{a}$ \\
\hline
\end{tabular}

Fifteen days after treatment

\begin{tabular}{lllllll}
\hline 1986 & & & 1987 & \\
\cline { 1 - 1 } treatment & $n$ & N-content & & treatment & $n$ & N-content \\
control & 2 & $42 \mathrm{a}$ & & control & 4 & $25 \mathrm{a}$ \\
water & 2 & $44 \mathrm{ac}$ & & water & 2 & $28 \mathrm{a}$ \\
hd1 & 2 & $38 \mathrm{bc}$ & & hd & 8 & $26 \mathrm{a}$ \\
hd2 & 4 & $37 \mathrm{~b}$ & & & \\
\hline
\end{tabular}

ment A (31.1 and $20.7 \mathrm{~g} \mathrm{~kg}^{-1}$, respectively) on $25 \mathrm{July}$ (day 207). At the final harvest, the amount of soluble carbohydrate in treatment $\mathrm{E}\left(8.9 \mathrm{~g} \mathrm{~kg}^{-1}\right)$ was significantly lower as compared to treatment $\mathrm{A}\left(31.3 \mathrm{~g} \mathrm{~kg}^{-1}\right)$.

\section{Discussion}

The effect of honeydew on gas exchange of leaves

Data requirement. In the simulation model constructed to predict damage by $S$. avenae in winter wheat, published information on effects of $S$. avenae on crop physiology was used for parameterization (Van Roermund et al., 1986a, b). Preliminary runs with the model revealed the need for additional information on the effect of honeydew on leaf carbon dioxide assimilation because simulated yield was sensitive to the parameter values used, whereas the parameter estimates were uncertain.

Early experiments concerning the effect of honeydew on carbon dioxide assimilation of wheat leaves considered effects both within five hours and one week after application (Rabbinge et al., 1981). In these experiments, statistically significant reductions of the rate of carbon dioxide assimilation at high irradiance, the initial light use efficiency and the ratio of internal and ambient carbon dioxide concentrations were found immediately following application. These effects were attributed to impaired carbon dioxide 354

Neth. J. Pl. Path. 96 (1990) 
Table 5. Grain weight $\left(10^{-6} \mathrm{~kg}\right)$, leaf area index $\left(\mathrm{m}^{2} \mathrm{~m}^{-2}\right)$, leaf weight $\left(\mathrm{kg} \mathrm{ha}^{-1}\right)$ and green leaf area duration $\left(\mathrm{m}^{2} \mathrm{~m}^{-2}\right.$ day) of winter wheat at three treatments on 'de Bouwing' in 1984. Treatments, not followed by the same letter are significantly different $(p<0.05)$. Treatment A: weekly chemical control of aphids from DC 71; treatment B: weekly chemical control of aphids from DC 73; treatment E: no chemical control of aphids.

\begin{tabular}{|c|c|c|c|c|c|c|c|c|c|}
\hline \multirow[t]{3}{*}{ Date } & \multicolumn{9}{|c|}{ Treatment } \\
\hline & \multicolumn{3}{|l|}{ A } & \multicolumn{3}{|l|}{ B } & \multicolumn{3}{|l|}{$\mathrm{E}$} \\
\hline & $\begin{array}{l}\text { grain } \\
\text { weight }\end{array}$ & $\begin{array}{l}\text { leaf } \\
\text { area } \\
\text { index }\end{array}$ & $\begin{array}{l}\text { leaf } \\
\text { weight }\end{array}$ & $\begin{array}{l}\text { grain } \\
\text { weight }\end{array}$ & $\begin{array}{l}\text { leaf } \\
\text { area } \\
\text { index }\end{array}$ & $\begin{array}{l}\text { leaf } \\
\text { weight }\end{array}$ & $\begin{array}{l}\text { grain } \\
\text { weight }\end{array}$ & $\begin{array}{l}\text { leaf } \\
\text { area } \\
\text { index }\end{array}$ & $\begin{array}{l}\text { leaf } \\
\text { weight }\end{array}$ \\
\hline 20 June & & 4.7 & 1922 & & & & & & \\
\hline 27 June & & 3.3 & 1398 & & & & & & \\
\hline 3 July & & 3.4 & 1619 & & & & & & \\
\hline 11 July & $12.3 \mathrm{a}$ & $2.9 \mathrm{k}$ & $1383 \mathrm{p}$ & & & & $13.1 \mathrm{a}$ & $2.7 \mathrm{k}$ & $1256 \mathrm{p}$ \\
\hline $18 \mathrm{July}$ & $18.2 \mathrm{a}$ & $3.1 \mathrm{k}$ & $1401 p$ & & & & $18.8 \mathrm{a}$ & $3.2 \mathrm{k}$ & $1365 \mathrm{p}$ \\
\hline 25 July & $20.4 \mathrm{a}$ & $2.2 \mathrm{k}$ & $1412 p$ & $19.9 \mathrm{a}$ & $2.1 \mathrm{k}$ & $1239 p$ & $20.3 \mathrm{a}$ & $2.0 \mathrm{k}$ & $1312 p$ \\
\hline 31 July* & $20.3 \mathrm{a}$ & $1.8 \mathrm{k}$ & $1056 p$ & $18.6 \mathrm{a}$ & $1.5 \mathrm{k}$ & $892 \mathrm{pq}$ & $20.4 \mathrm{a}$ & $1.2 \mathrm{k}$ & $746 q$ \\
\hline 8 August & $38.3 \mathrm{a}$ & $0.8 \mathrm{k}$ & $422 p$ & $38.7 \mathrm{a}$ & $0.5 \mathrm{k}$ & $277 p$ & $40.0 \mathrm{a}$ & $0.4 \mathrm{k}$ & $217 p$ \\
\hline 23 August & $39.5 \mathrm{a}$ & $0.0 \mathrm{k}$ & $0 \mathrm{p}$ & $37.8 \mathrm{a}$ & $0 \mathrm{k}$ & $0 \mathrm{p}$ & $40.0 \mathrm{a}$ & $0.1 \mathrm{k}$ & $5 p$ \\
\hline $\begin{array}{l}\text { Green leaf } \\
\text { area duration }\end{array}$ & $163 \mathrm{e}$ & & & $157 \mathrm{e}$ & & & $151 \mathrm{e}$ & & \\
\hline
\end{tabular}

* significant block effect grain weight, leaf area index and leaf weight $(p<0.05)$.

exchange due to blocking of the stomata. The results of the carbon dioxide assimilation measurements one week after application were not conclusive due to lack of a control treatment.

Plant material. In the present study, the condition of the plant material differed considerably between the two experimental years. Compared to 1986, the leaf nitrogen content of control plants was significantly lower in 1987, resulting in lower rates of carbon dioxide assimilation at high irradiance at a similar development stage. These differences were presumably caused by weather conditions before the experiment started. Average daily total global radiation during the four weeks preceding the experiments amounted to $1835 \mathrm{~J} \mathrm{~m}^{-2} \mathrm{~d}^{-1}$ in 1986 and $1577 \mathrm{~J} \mathrm{~m}^{-2} \mathrm{~d}^{-1}$ in 1987 . Thus, the level of maximum photosynthesis in 1987 may reflect adaptation of the leaves to the conditions of lower light intensity. Moreover, successive periods of abundant precipitation and drought in 1987 may have adversely affected nitrogen uptake by the crop. The values of carbon dioxide assimilation in 1987 are comparable to those reported by Rabbinge et al. (1981).

Honeydew amount and leaf coverage. The amount of sugars recovered from the leaves one day after application differed considerably between 1986 and 1987. Possible causes for the differences are differences in leaf wetness and mechanical effects of wind. In 1987, honeydew was applied to wet leaves, whereas in 1986 leaves were dry. In 1986, treated potted plants were placed on a roofed area at the experimental site, which reduced mutual cleaning of leaves in the wind.

Neth. J. Pl. Path. 96 (1990) 

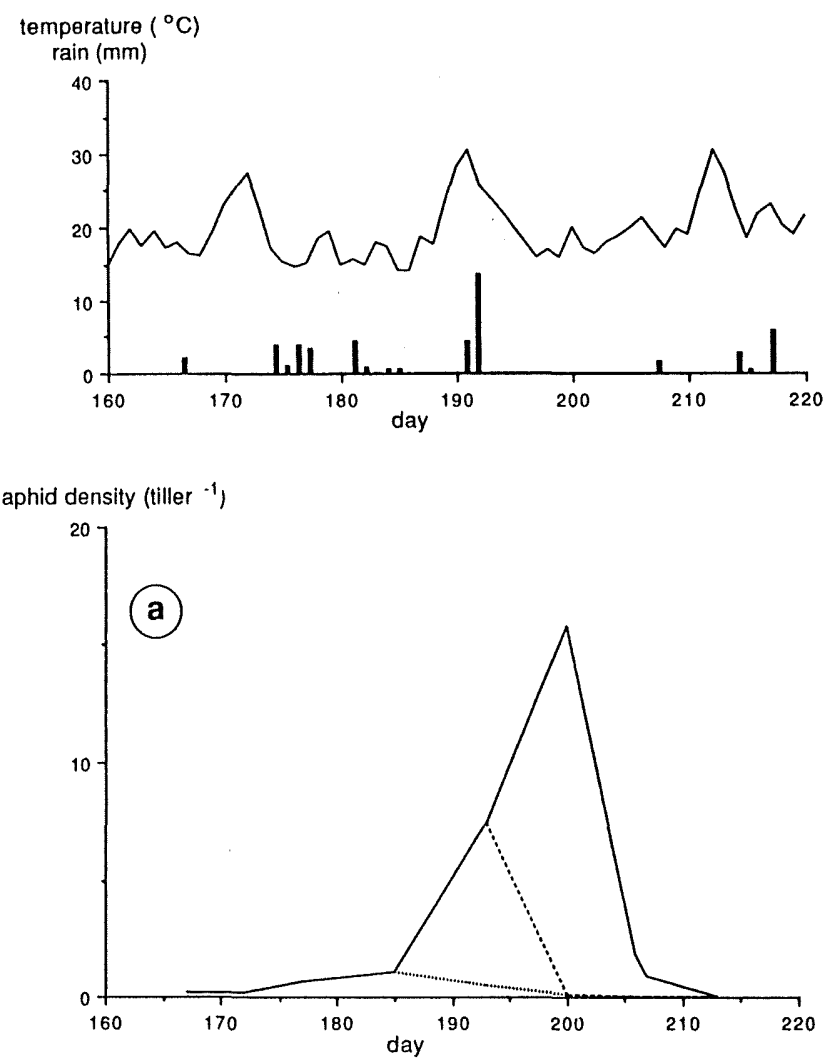

Fig. 5. Aphid density (tiller ${ }^{-1}$ ) at 'de Bouwing' (a) and 'de Eest' (b) during the field experiment in 1984. Treatments at 'de Bouwing' are A ( …...... $)$ B ( - ...- ) and E ( _


top of the graphs daily maximum temperature $\left({ }^{\circ} \mathrm{C},-(-)\right.$ and precipitation (mm, bars) during the experiment are indicated. A description of the treatments is given in the text.

Fifteen days after treatment in 1987 , the amount of dry matter recovered from the leaf surface of treated leaves did not differ from the control. The decrease is attributed to the heavy rains between 13 and $20 \mathrm{July}$, and to consumption by phyllosphere fungi.

Fokkema et al. (1983) recovered $6.3 \mathrm{~g} \mathrm{~m}^{-2}$ honeydew (as glucose) from leaves of glasshouse-grown wheat infested with more than one hundred aphids per ear. Unfortunately, the duration of the exposition of the plants to the population was not reported. Rabbinge and Coster (1984) measured honeydew production rates of $S$. avenae on winter wheat plants (DC 45-75). Using their data and the aphid infestation of treatment $\mathrm{E}$ at 'de Eest' (which started in DC 71), we calculated the total amount of honeydew produced until DC 77 to be approximately $7 \mathrm{~g} \mathrm{~m}^{-2}$ (leaf area index $3.4 \mathrm{~m}^{2} \mathrm{~m}^{-2}$ ). Under field conditions, the aphid population only occasionally exceeds densities of 30 aphids per ear and honeydew will be diluted by dew and rain. Thus, the amount of honeydew applied in 1986 represented a situation with a large aphid infestation, whereas the amount applied in 1987 was comparable to commonly occurring deposits. 

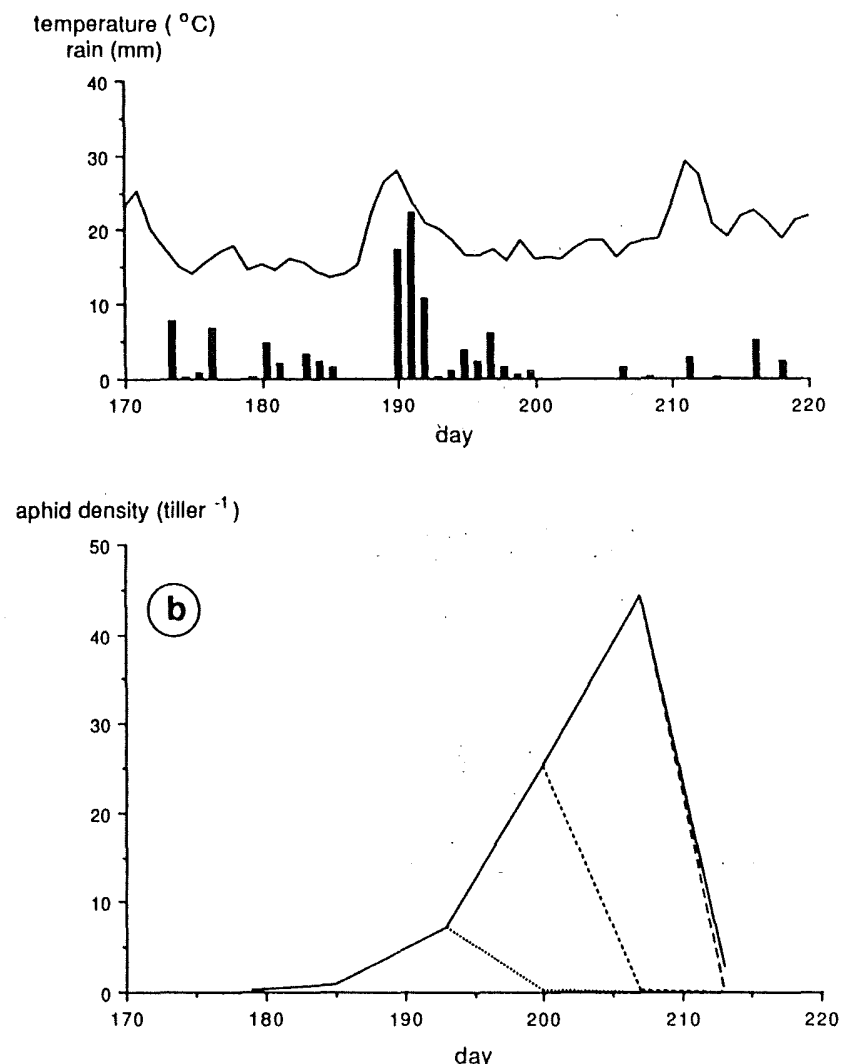

Effects of honeydew on carbon dioxide assimilation - light response: one and three days after treatment. One day after treatment with honeydew substitute, effects on the carbon dioxide assimilation - light response were similar in both experimental years. Values of the rate of dark respiration $\left(R_{\mathrm{d}}\right)$ were increased significantly compared to the control, in 1986 only at the larger amount applied. Neither carbon dioxide assimilation at high irradiance $\left(P_{\mathrm{m}}\right)$ nor the initial light use efficiency $(\epsilon)$ were significantly affected. Rabbinge et al. (1981) found a significant reduction of $P_{\mathrm{m}}$ and $\epsilon$ immediately after application of honeydew. No information was given on $R_{\mathrm{d}}$. These authors attributed the reduction of $P_{\mathrm{m}}$ and $\epsilon$ to coverage of stomata, the size of the effect depending on the fraction of stomata covered. Apparently, the coverage of stomata affects carbon dioxide assimilation only for a short period of time. The fraction of stomata covered may decrease due to dew, crystallization of honeydew and removal of honeydew due to effects of stomatal movement. Scanning electron microscope photographs taken one day after honeydew application showed gaps around the stomata in the further intact honeydew film (personal communication R. Rabbinge, 1986, and own observations). Conclusions will be possible when the fraction of stomata covered by honeydew is estimated in combination with gas exchange parameters. New techniques for the former have recently been developed (Hurej and Van der Werf, in prep.).

Increased values of $R_{\mathrm{d}}$ one day after honeydew application have been tentatively 


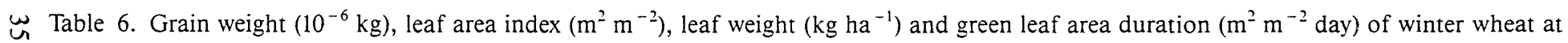
$\infty$ four treatments on 'de Eest' in 1984. Treatments, not followed by the same letter are significantly different $(p<0.05)$. Treatment A: weekly chemical control of aphids from DC 71; treatment C: weekly chemical control of aphids from DC 75; treatment D: weekly chemical control of aphids from DC 77; treatment E: no chemical control of aphids.

\begin{tabular}{|c|c|c|c|c|c|c|c|c|c|c|c|c|}
\hline \multirow[t]{3}{*}{ Date } & \multicolumn{12}{|c|}{ Treatment } \\
\hline & \multicolumn{3}{|l|}{$\mathrm{A}$} & \multicolumn{3}{|l|}{$C$} & \multicolumn{3}{|l|}{$\mathrm{D}$} & \multicolumn{3}{|l|}{$\mathrm{E}$} \\
\hline & $\begin{array}{l}\text { grain } \\
\text { weight }\end{array}$ & $\begin{array}{l}\text { leaf } \\
\text { area } \\
\text { index }\end{array}$ & $\begin{array}{l}\text { leaf } \\
\text { weight }\end{array}$ & $\begin{array}{l}\text { grain } \\
\text { weight }\end{array}$ & $\begin{array}{l}\text { leaf } \\
\text { area } \\
\text { index }\end{array}$ & $\begin{array}{l}\text { leaf } \\
\text { weight }\end{array}$ & $\begin{array}{l}\text { grain } \\
\text { weight }\end{array}$ & $\begin{array}{l}\text { leaf } \\
\text { area } \\
\text { index }\end{array}$ & $\begin{array}{l}\text { leaf } \\
\text { weight }\end{array}$ & $\begin{array}{l}\text { grain } \\
\text { weight }\end{array}$ & $\begin{array}{l}\text { leaf } \\
\text { area } \\
\text { index }\end{array}$ & $\begin{array}{l}\text { leaf } \\
\text { weight }\end{array}$ \\
\hline 27 June & & 4.52 & 1930 & & & & & & & & & \\
\hline 3 July & & 3.99 & 1823 & & & & & & & & & \\
\hline 11 July & & 4.00 & 1823 & & & & & & & & & \\
\hline 18 July & $11.59 \mathrm{a}$ & $4.03 \mathrm{k}$ & $1933 \mathrm{p}$ & & & & & & & $10.81 \mathrm{a}$ & $4.02 \mathrm{k}$ & $1887 \mathrm{p}$ \\
\hline 25 July & $16.25 \mathrm{a}$ & $3.79 \mathrm{k}$ & $2162 \mathrm{p}$ & & & & & & & $16.15 \mathrm{a}$ & 3.171 & $1946 \mathrm{p}$ \\
\hline 31 July & $20.73 \mathrm{a}$ & $3.10 \mathrm{k}$ & $1781 \mathrm{pq}$ & $19.74 \mathrm{a}$ & $3.25 \mathrm{k}$ & $2014 p$ & & & & $20.03 \mathrm{a}$ & $2.67 \mathrm{l}$ & $1484 \mathrm{q}$ \\
\hline 8 August & $32.74 \mathrm{a}$ & $2.61 \mathrm{k}$ & $1304 \mathrm{p}$ & $30.30 \mathrm{ab}$ & $2.31 \mathrm{kl}$ & $1147 \mathrm{pq}$ & $29.21 \mathrm{~b}$ & $1.99 \mathrm{kl}$ & $988 \mathrm{q}$ & $29.30 \mathrm{c}$ & 1.851 & $922 \mathrm{q}$ \\
\hline 15 August* & $34.56 \mathrm{a}$ & $1.53 \mathrm{k}$ & $806 \mathrm{p}$ & $33.68 \mathrm{a}$ & 0.911 & $481 \mathrm{q}$ & $30.62 \mathrm{~b}$ & 0.731 & $396 \mathrm{q}$ & $30.53 \mathrm{~b}$ & 0.891 & $464 \mathrm{q}$ \\
\hline 23 August & $35.61 \mathrm{a}$ & $0.22 \mathrm{k}$ & $121 \mathrm{p}$ & $32.60 \mathrm{a}$ & 0.081 & $57 \mathrm{p}$ & $32.25 \mathrm{a}$ & $0.10 \mathrm{l}$ & $61 \mathrm{p}$ & $31.88 \mathrm{a}$ & 0.041 & $24 \mathrm{p}$ \\
\hline 31 August & $34.18 \mathrm{a}$ & $0.03 \mathrm{k}$ & $20 \mathrm{p}$ & $33.77 \mathrm{a}$ & $0.00 \mathrm{k}$ & $0 \mathrm{p}$ & $31.91 \mathrm{a}$ & $0.00 \mathrm{k}$ & $0 \mathrm{p}$ & $31.82 \mathrm{a}$ & $0.00 \mathrm{k}$ & $0 \mathrm{p}$ \\
\hline $\begin{array}{l}\text { Green leaf } \\
\text { area duration }\end{array}$ & $179 \mathrm{e}$ & & & $172 \mathrm{f}$ & & & $168 \mathrm{f}$ & & & $160 \mathrm{~g}$ & & \\
\hline
\end{tabular}

* Significant block effect grain weight, leaf area index and leaf weight $(p<0.05)$.

2
2
2
2
2
2 

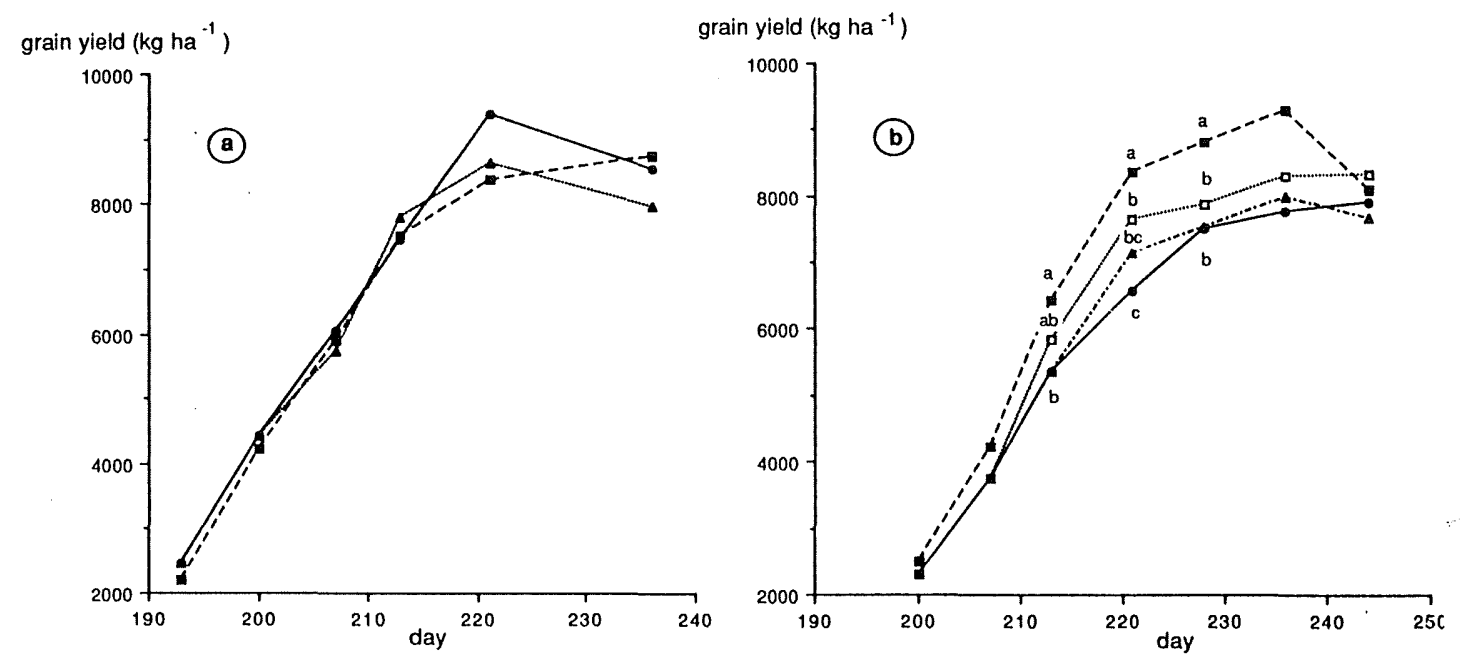

Fig. 6. Grain yield ( $\mathrm{kg} \mathrm{ha}^{-1}$ at 'de Bouwing' (a) and 'de Eest' (b). Treatments at 'de Bouwing' are A ( - . N significant differences between treatments were found. Treatments at 'de Eest' are A ( -... - and $\mathrm{E}(-\bullet-)$. Similar or no letters for a treatment indicate no significant differences $(p<$ $0.05)$. A description of the treatments is given in the text.

ascribed to stimulation of phyllosphere saprophytic micro-organisms by SmedegaardPetersen (1982) and Smedegaard-Petersen and Tolstrup (1985) who measured significant increases of $\mathrm{O}_{2}$ consumption by leaves of barley, 12-24 hours after inoculation with saprophytic Cladosporium spp. and Alternaria alternata. The response of the plants subsequently declined until values comparable to the control were reached after five to seven days. In our experiments, three days after honeydew application no effects on dark respiration could be found. Thus, stimulation of the growth of the population micro-organisms by honeydew, if it occurred in our experiments, seemed limited to a few days. This agrees with results of Fokkema et al. (1983) who studied growth of populations of saprophytic fungi and bacteria on leaves of spring wheat in vitro after application of $4.5 \mathrm{~g} \mathrm{~m}^{-2} 15 \%$ glucose solution. Populations increased exponentially until three days after application when the rate of increase decreased considerably even though the amount of glucose had only been consumed by $50 \%$ and still exceeded the amount of naturally occurring glucose.

Effects of honeydew on carbon dioxide assimilation - light response: fifteen days after treatment. Fifteen days after treatment with honeydew substitute, the effects on the carbon dioxide assimilation - light response differed between the experimental years. The differences can be ascribed to differences in environmental conditions. In 1986, high temperature and low relative humidity caused crystallization of honeydew substitute and most likely reduced the growth of the phyllosphere mycoflora (Bashi and Fokkema, 1977). Therefore, the effects found were probably caused by honeydew per $s e$, whereas the moderate temperatures and the occurrence of dew in 1987 were conducive to growth of saprophytic micro-organisms, which confounded the effects of honeydew. 
In 1986, a complex of effects was found fifteen days after double application of honeydew substitute: an increase in $R_{\mathrm{d}}$ and decreases in $P_{\mathrm{m}}$, mesophyll conductance $\left(g_{\mathrm{m}}\right)$ and leaf nitrogen content. Macroscopically, chlorotic areas were visible, especially at sites which were covered by honeydew substitute. Similar symptoms were observed in field experiments under hot and dry conditions (Vereijken, 1979; own observation, July 1984). Injury by honeydew under such extreme environmental conditions may be caused by prolonged exposure of leaves to the high osmotic potential of the honeydew solution as was suggested by Vereijken (1979). Several authors have reported increases in $R_{\mathrm{d}}$ as a general consequence of repair processes in injured plants (e.g. Kosuge and Kimpel, 1981). The decrease in $P_{\mathrm{m}}$ after fifteen days appears to be the result of changes in biochemical processes in the leaf rather than coverage or malfunctioning of stomata as no changes in the ratio of internal and ambient carbon dioxide concentrations were found.

In 1987 fifteen days after application, differences in the amount of honeydew between treatments with water and honeydew substitute were absent. Honeydew was washed off by the heavy rains or was consumed by the phyllosphere mycoflora. Apart from a decrease in the initial light use efficiency, no significant effects were found after treatment. It is tempting to attribute the decrease of initial light use efficiency to absorption of photosynthetically active radiation by the phyllosphere mycoflora. However, as only reflection and not transmission of PAR was measured, no conclusion can be drawn. Rabbinge et al. (1981) found $6 \%$ reduction of absorption of photosynthetically active radiation by flag leaves of spring wheat, 48 days after treatment with honeydew at low relative humidity as compared to an untreated control. No information was given on the statistical significance of the effect.

The relation between relative humidity and the effect of honeydew on wheat leaves is also found in other reports. In a greenhouse experiment at relatively dry conditions (40-70\% relative humidity), Rabbinge et al. (1981) observed that leaves treated with honeydew yellowed and died more quickly than controls. Under field conditions, Fokkema et al. (1979) found no evidence of accelerated senescence after spraying flag leaves of spring wheat with nutrients, consisting of $2 \%$ glucose, $0.5 \%$ yeast extract and 0.05 'Tween 80', a mixture of Aurobasidium pullulans, Cladosporium spp. and nutrients, and water respectively. The experiments took place in 1975 and 1977, years with moderate temperature and relative humidity.

The increases of the rate of transpiration relative to the rate of carbon dioxide assimilation, which were found both one and fifteen days after double application of honeydew substitute in 1986 (Table 3), may have been caused by leaf exudation (Ajayi and Dewar, 1983) due to the high osmotic potential of honeydew. In 1987, no effects on the $P / T$ ratio were observed. These results support the surmised injurious effect of honeydew substitute under hot and dry conditions.

\section{Quantification of damage in field experiments}

In the field experiment at 'de Bouwing', the lack of significant effects is partly attributable to the lower aphid densities and to the large variation in the data caused by the heterogeneity of the soil. An alternative explanation concerns the condition of the crop at the onset of the experiment. At flowering, a relatively large reserve of soluble carbohydrates was available, amounting to $18 \%$ of the total stem dry matter compared to $9 \%$ at 'de Eest'. Also, leaf area index at anthesis exceeded the value on 'de Eest', 
contributing to a large amount of carbohydrates available for grain growth. This may have allowed more compensation of the effects of aphid infestation than at 'de Eest'. Quantitative evaluation of this hypothesis is possible by means of a simulation model of aphid damage.

Yield of grain dry matter decreased between the penultimate and final harvest in some treatments at both experimental locations. The maximum decrease was observed in treatment $A$ at 'de Eest' and amounted to $1176 \pm 696$ (SEM) kg ha ${ }^{-1}$. Apart from sampling errors, the decrease may be due to respiratory loss, at 'de Eest' aggravated by the presence of green plant parts after grain filling had ceased.

In the field experiment at 'de Eest', grain yield was reduced by aphid infestation on the ears. Of the three yield components, tiller and grain density were not affected but grain weight was reduced significantly. Leaf area duration was reduced as a result of accelerated leaf death. The results confirm earlier reports by Wratten $(1975,1978)$, Lee et al. (1981a, b) and Rabbinge et al. (1981). Soluble carbohydrates seem to be exhausted more quickly in the presence of aphids (cf. Wratten and Redhead, 1976). Ear nitrogen content was increased and leaf nitrogen content was decreased at the time the aphid population peaked. At the final harvest, no differences in nitrogen content of plant parts were found.

Lee et al. (1981a) found early infestations of $S$. avenae on spring and winter wheat (DC 61 to DC 75) to be more damaging than late infestations (DC 75 to DC 91). The size of the largest infestation was almost four times as large as in the present experiments. Our results indicate that the crop remains susceptible until mid milky ripe (DC 75).

Differences in experimental design and variability in results are inherent to a purely experimental research approach and call for a large body of information before general conclusions on damage by $S$. avenae can be drawn (Entwistle and Dixon, 1987). Alternatively, empirical information on processes involved in the interaction between the grain aphid and the crop can be integrated with crop-physiological knowledge in a simulation model. Then, conclusions on the effect of aphid injury on yield are of a causal rather than a statistical nature. Also, the simulation model can be used to evaluate the quantitative consequences for grain yield of uncertainty in the relation between injury by honeydew and weather conditions. The results of such analysis are presented elsewhere (Rossing, 1991).

\section{Acknowledgements}

Thanks are due to Rob Groot, mr W. de Jager of 'de Bouwing', Herman van Roermund and $\mathrm{mr}$ J. Sinke of 'de Eest' for their contribution to the field experiments. We thank prof. dr R. Rabbinge, dr W. van der Werf and prof. dr J.C. Zadoks for critically reading the manuscript and helpful suggestions.

\section{Samenvatting}

Simulatie van schade in wintertarwe veroorzaakt door de grote graanluis Sitobion avenae. 1. Kwantificering van de effekten van honingdauw op gaswisseling in bladeren en van populaties bladluizen van verschillende omvang op gewasgroei 
Schade in wintertarwe veroorzaakt door de grote graanluis Sitobion avenae F., werd bestudeerd in laboratorium- en veldproeven.

De vlagbladeren van wintertarweplanten werden behandeld met honingdauw-substituut-oplossing. Eén en vijftien dagen na behandeling werden de netto fotosynthesesnelheid en de transpiratie van de behandelde bladeren gemeten. Na één dag werd een verhoging van de donkerademhaling gemeten in vergelijking met de controle. Vijftien dagen na behandeling werden verschillende resultaten gevonden in de twee experimentele jaren. Onder warme en droge omstandigheden in 1986 was de donkerademhaling hoger terwijl de fotosynthese bij verzadigende lichtintensiteiten, de geleidbaarheid van het mesofyl en het stikstofgehalte van de bladeren lager waren dan in de controle. Ook werden chlorotische vlekken waargenomen. Bij gematigde temperaturen en relatieve vochtigheid in 1987 werd een verlaging van de initiële efficiëntie van lichtbenutting gemeten.

In twee veldexperimenten werd een natuurlijke aantasting van voornamelijk S. avenae op verschillende tijdstippen chemisch bestreden. Op deze wijze werden aantastingen van verschillende omvang en duur verkregen. Vanaf bloei van het gewas werden wekelijks gewasmonsters geanalyseerd. Een natuurlijke aantasting vanaf DC 71 met een bladluisindex van 182 en een piekdichtheid van 15,8 bladluizen per halm, leidde niet tot significante reduktie van de gewasproduktie. Een aantasting beginnend in DC 71 met een bladluisindex van 544 en een piekdichtheid van 44,4 leidde tot significante verlaging van de bladoppervlakteïndex, de blad biomassa, de hoeveelheid water-oplosbare koolhydraten en het korrelgewicht. Geen effekten werden waargenomen op halm- en korreldichtheid of op het stikstofgehalte van plantedelen bij de oogst.

\section{References}

Ajayi, O. \& Dewar, A.M., 1983. The effects of barley yellow dwarf virus, aphids and honeydew on Cladosporium infection of winter wheat and barley. Annals of Applied Biology 102: 57-65.

Ankersmit, G.W. \& Carter, N., 1981. Comparison of the epidemiology of Metopolophium dirhodum and Sitobion avenae on winter wheat. Netherlands Journal of Plant Pathology 87: 71-81.

Bashi, E. \& Fokkema, N.J., 1977. Environmental factors limiting growth of Sporobolomyces roseus, an antagonist of Cochliobolus sativus on wheat leaves. Transactions of the British Mycological Society 68: 17-25.

Carter, N., Dixon, A.F.G. \& Rabbinge, R., 1982. Cereal aphid populations: biology, simulation and prediction. Pudoc, Wageningen, $91 \mathrm{pp}$.

Drenth, H., Hoek, J., Daamen, R.A., Rossing, W.A.H., Stol, W. \& Wijnands, F.G., 1989. An evaluation of the crop physiological and epidemiological information in EPIPRE, a computerbased advisory system for pests and diseases in winter wheat in the Netherlands. Bulletin EPPO/ EPPO Bulletin 19: 417-424

Entwistle, J.C. \& Dixon, A.F.G., 1987. Short-term forecasting of wheat yield loss caused by the grain aphid (Sitobion avenae) in summer. Annals of Applied Biology 111:489-508.

Fokkema , N.J., Kastelein, P. \& Post, B.J., 1979. No evidence for acceleration of leaf senescence by phyllosphere saprophytes of wheat. Transactions of the British Mycological Society 72: 312-315.

Fokkema, N.J., Riphagen, I., Poot, R.J. \& Jong, C. de, 1983. Aphid honeydew, a potential stimulant of Cochliobolus sativus and Septoria nodorum and the competitive role of saprophytic mycoflora. Transactions of the British Mycological Society 81: 355-363.

Goudriaan, J., 1982. Potential production processes. In: F.W.T. Penning de Vries \& H.H. van 
Laar (Eds), Simulation of plant growth and crop production. Pudoc, Wageningen, p. 98-113.

Goudriaan, J. \& Laar, H.H. van, 1978. Relations between leaf resistance, $\mathrm{CO}_{2}$ concentration and $\mathrm{CO}_{2}$ assimilation in maize, beans, lalang grass and sunflower. Photosynthetica 12: 241-249.

Holt, J., Griffiths, E. \& Wratten, S.D., 1984. The influence of wheat growth stage on yield reductions caused by the rose-grain aphid, Metopolophium dirhodum. Annals of Applied Biology 105: 7-14.

Kosuge, T. \& Kimpel, J.A., 1981. Energy use and metabolic regulation in plant-pathogen interactions. In: P.G. Ayres (Ed.), Effects of disease on the physiology of the growing plant. Cambridge University Press, Cambridge, p. 29-45.

Kropff, M.J., 1987. Physiological effects of sulphur dioxide. 1. The effect of $\mathrm{SO}_{2}$ on photosynthesis and stomatal regulation of Vicia faba L. Plant, Cell and Environment 10: 753-760.

Lee, G., Wratten, S.D. \& Kenyi, K.B.L., 1981a. The effects of growth stage in cereals on yield reductions caused by aphids. Proceedings 1981 British Crop Protection Conference - Pests and Diseases, p. 449-456.

Lee, G., Stevens, D.J., Stokes, S. \& Wratten, S.D., 1981b. Duration of cereal aphid populations and the effects on wheat yield and breadmaking quality. Annals of Applied Biology 98: 169-178.

Louwerse, W. \& Oorschot, J.L.P. van, 1969. An assembly for routine measurements of photosynthesis, respiration and transpiration of intact plants under controlled conditioning. Photosynthetica 3: 305-315.

Rabbinge, R. \& Coster, G., 1984. Some effects of cereal aphids on growth and yield of winter wheat. In: P. Barley \& D. Swinger (Eds), Proc. Fourth Austr. Appl. Entomol. Res. 24-28 Sept. 1984. p. 163-169.

Rabbinge, R., Drees, E.M., Graaf, M.-van der, Verberne, F.C.M. \& Wesselo, A., 1981. Damage effects of cereal aphids in wheat. Netherlands Journal of Plant Pathology 87: 217-232.

Rabbinge, R. \& Mantel, W.P., 1981. Monitoring for cereal aphids in winter wheat. Netherlands Journal of Plant Pathology 87: 25-29.

Rautapää, J., 1966. The effect of the English grain aphid Macrosiphum avenae on yield and quality of wheat. Annales Agriculturae Fenniae 5: 334-341.

Roermund, H.J.W. van, Groot, J.J.R., Rossing, W.A.H. \& Rabbinge, R., 1986a. Calculation of aphid damage in winter wheat, using a simulation model. Mededelingen van de Faculteit Landbouwwetenschappen Rijsuniversiteit Gent 51: 1125-1130.

Roermund, H.J.W. van, Groot, J.J.R., Rossing, W.A.H. \& Rabbinge, R., 1986b. Simulation of aphid damage in winter wheat. Netherlands Journal of Agricultural Science 34: 488-493.

Rossing, W.A.H., 1991. Simulation of damage in winter wheat caused by the grain aphid Sitobion avenae. 2. Construction and evaluation of a simulation módel. Accepted by Netherlands Journal of Plant Pathology. SAS, 1985. SAS User's Guide: Statistics. Version 5 Edition. Cary, N.C. SAS Institute Inc. Schaffer, P.A. \& Somogyi, M., 1933. Copper-iodometric reagents for sugar determination. Journal of Biological Chemistry 100: 695-713.

Smedegaard-Petersen, V., 1982. The effect of defence reactions on the energy balance and yield of resistant plants. In: R.K.S. Wood (Ed.), Active defence mechanisms in plants. Plenum, p. 299-315.

Smedegaard-Petersen, V. \& Tolstrup, K., 1985. The limiting effect of disease resistance on yield. Annual Review of Phytopathology 23: 475-490.

Snedecor, G.W. \& Cochran, W.G., 1980. Statistical methods. Iowa State University Press, 7th edition.

Vereijken, P.H., 1979. Feeding and multiplication of three aphid species and their effect on yield of winter wheat. Agricultural Research Reports 888.

Vertregt N. \& Verhagen, W., 1979. De bepaling van reservekoolhydraten in grassen. CABO-verslag 23.

Ward, S.A., Rabbinge, R. \& Mantel, W.P., 1985. The use of incidence counts for estimation of 
aphid populations. 1. Minimum sample size for required accuracy. Netherlands Journal of Plant Pathology 91: 93-99.

Watt, A.D., 1983. The influence of forecasting on cereal aphid control strategies. Crop Protection 2: 417-429.

Wellings, P.W., Ward, S.A., Dixon, A.F.G. \& Rabbinge, R., 1989. Crop loss assessment. In: A.K. Minks \& P. Harrewijn (Eds), Aphids, their biology, natural enemies and control. Volume $2 \mathrm{C}$, Elsevier Science Publishers, Amsterdam, p. 49-64.

Wratten, S.D., 1975. The nature and effects of the aphids Sitobion avenae and Metopolophium dirhodum on growth of wheat. Annals of Applied Biology 79: 27-34.

Wratten, S.D., 1978. Effects of feeding position of the aphids Sitobion avenae and Metopolophium dirhodum on wheat yield and quality. Annals of Applied Biology 90: 11-20.

Wratten, S.D. \& Redhead, P.C., 1976. Effects of cereal aphids on the growth of wheat. Annals of Applied Biology 84: 437-440.

Zadoks, J.C., 1985. On the conceptual basis of crop loss assessment: The threshold theory. Annual Review of Phytopathology 23: 455-473.

Zadoks, J.C., 1989. EPIPRE, a computer-based decision support system for pest and disease control in wheat: Its development and implementation in Europe. In: K.J. Leonard \& W.E. Fry (Eds), Plant disease epidemiology. Volume 2, p. 3-29.

Zadoks, J.C., Chang, T.T. \& Konzak, C.F., 1974. A decimal code for the growth stages of cereals. Eucarpia Bulletin 7: 42-52. 